\title{
THE AWARDING OF POST-DIVORCE MAINTENANCE TO A MUSLIM EX-WIFE AND CHILDREN IN THE SOUTH AFRICAN COURTS: THE INTERACTION BETWEEN DIVINE AND SECULAR LAW
}

\author{
Razaana Denson \\ BA LLB HDE LLM \\ Advocate of the High Court \\ Lecturer in Private Law \\ Nelson Mandela Metropolitan University \\ Port Elizabeth \\ Marita Carnelley \\ BA LLB LLM PhD \\ Professor of Law, \\ University of KwaZulu-Natal, Pietermaritzburg
}

\section{SUMMARY}

The article discusses the differences between the South African civil law and Islamic law with specific reference to post-divorce spousal maintenance as well as postdivorce maintenance of children in light of recent case law, Mahomed $v$ Mahomed [2009] JOL 23733 (ECP). The issue of post-divorce spousal maintenance is especially controversial and it is noted that in both systems the issue should not be seen in isolation, but in conjunction with the other protection possibilities within each of these systems. The apparent conflict between the South African constitutional principles and the principles of Islam is noted and compared to the Indian legal and constitutional experience, although reference is also made to the Algerian legal position. Drawing an analogy with the South African legal developments vis-à-vis customary marriages, the article concludes and submits that any enactment by the South African legislature, dealing with the maintenance of spouses and children after divorce, whether in the format of the Muslim Marriage Bill as set out in the 2003 South African Law Reform Commission Report, or in any other format, should take cognizance of the rulings and teachings of Islam.

"The challenge posed to the law and legal institutions within a democratic secular state is the manner in which and the extent to which it accommodates 
individual choice in matters of morality and religion. A tolerant society seeks to maximise individual liberty and freedom of choice. Implementation has to be technically feasible within the dominant system whilst maintaining the integrity of Muslim Personal Law".

Islamic marriages were originally not recognised in terms of the South African law since such marriages were regarded as contra bonos mores for being potentially polygamous. ${ }^{2}$ These marriages are still not recognised - no longer for that reason - but mainly because the legislative process aimed at such recognition seems to have stalled. ${ }^{3}$ This non-recognition has led to hardships, especially for women, ${ }^{4}$ as the effect thereof is that Muslim wives have no right to approach the South African secular courts for a divorce, but have to seek remedies within their faith. This solution is not always satisfactory as there is a lack of consensus about the available internal remedies and the fact that Muslim clerics cannot enforce the financial duties.

The focus of this article is solely on one aspect of Muslim divorces, namely post-divorce maintenance: maintenance for the children and the wife married in terms of Islamic law. This aspect has undergone some changes during the past few decades in South Africa. ${ }^{6}$ Although the duty of a parent to maintain a child has always been enforceable in the South African courts, ${ }^{7}$ the issue of Muslim spousal maintenance was problematic. Previously, as a result of the non-recognition of Muslim marriages, there were no enforceable

South African Law Commission Issue Paper 15 Project 59 Islamic Marriages and Related Matters (May 2000) 1 ("SALRC 2000"). South Africa is a religiously diverse country with approximately $1.5 \%$ of the 45 million persons professing the Islamic faith in 2001 (Statistics South Africa Census 2001 Primary Tables South Africa. Census '96 and 2001 Compared (2004) 24. Sourced electronically http://www.statssa.gov.za/census01/html/RSAPrimary pdf). For background, it should be noted that most South African Muslims are members of the Sunni branch of Islam (Mahida History of Muslims in South Africa: A Chronology. South African History Online. Sourced electronically http://www.sahistory.org.za/pages/libraryresources/online\%20books/history-muslims/1980.htm). These are divided in a further four Islamic schools of thought of which two are important in South Africa: Hanafi (propagated in South Africa mainly by Muslims in Gauteng and KwaZulu-Natal); Shafi'i (propagated in South Africa mainly by Muslims in the Cape). The other two are Maliki (followed in Algeria) and Hanbali (El Alami The Marriage Contract in Islamic Law (1992) 2).

2 Muslim marriages were found to be "contrary to the accepted customs and usages which are regarded as morally binding upon all members of our society" (Ismail $v$ Ismail 19831 SA 1006 (A) 1026; see also Seedat's Executors v The Master (Natal) 1917 AD 302 309; and Bronn v Frits Bronn's Executors 1890 Searle Law Reports 313 318).

3 See discussion below.

4 Rautenbach "Some Comments on the Current (and Future) Status of Muslim Personal Law in South Africa" 20042 PER 1.

5 Gabru "Dilemma of Muslim Women Regarding Divorce in South Africa" 20042 PER 4; Amien "Overcoming the Conflict between the Right to Freedom of Religion and Women's Rights to Equality: A South African Case Study of Muslim Marriages" 2006 Human Rights Quarterly 729 735; and SALRC 20009.

6 See in general Rautenbach "Islamic Marriages in South Africa: Quo Vadimus?" 2003 Koers 121-152 and the cases referred to hereunder.

7 Motan $v$ Joosub 1930 AD 6166 with reference to the Roman-Dutch writer Van Leeuwen (Censura Forensis (1.1.10.3)), noted obiter that both parents of a child, even where the child is regarded as illegitimate at the time as a result of the non-recognition of a religious marriage, are obligated to maintain the child. 
spousal maintenance claims for women married in terms of Muslim law in the South African courts.

The first change in this regard was the judgment of Ryland $v$ Edros. ${ }^{8}$ Although Muslim marriages were (and are) still not recognised in law, the court was prepared to enforce the contractual obligations between de facto monogamous Muslim spouses at the time of divorce as set out in the Shari'ah. ${ }^{9}$ The court ordered that arrear maintenance had to be paid, including maintenance for the post-divorce three month iddah waiting period, ${ }^{10}$ as prescribed by the tenets of Islamic law. ${ }^{11}$

In the 2009 case of Mahomed $v$ Mahomed ${ }^{12}$ the Port Elizabeth High Court granted a maintenance order in favour of a Muslim ex-wife and her minor daughter against her (former) husband to whom she was married to in terms of Islamic law. The marriage, according to the husband, already had ended in divorce. ${ }^{13}$ The court found that the wife was entitled to maintenance pendente lite (in the civil courts) irrespective of whether the husband had uttered the three talaqs or not. ${ }^{14}$ This seems to be a groundbreaking decision as it seems to allow Muslim wives the opportunity to claim postdivorce maintenance for a period longer than the three months iddah period where they are married in terms of Islamic law. It is important to note that the order was only an interim order made pendente lite: pending the (civil) divorce trial. ${ }^{15}$

For the sake of completeness it is noted that the enforcement of maintenance orders for Muslim wives during their marriages, including

19972 SA 690 (C).

711f-g.

10 Iddah can be described as three menstrual periods for a menstruating woman and three lunar months for a woman that does not menstruate (Vahed Islamic Family Law (2006) 33; Nasir The Status of Women under Islamic Law and under Modern Islamic Legislation 2ed (1994) 110-111; Moosa and Karbanee "An Exploration of Mata'a Maintenance in Anticipation of the Recognition of Muslim Marriages in South Africa: (Re-)opening a Veritable Pandora's Box?" 2004(2) Law, Democracy and Development 267 269; and Miller "Who says Muslim Women Don't have the Right to Divorce? A Comparison between AngloAmerican Law and Islamic Law" 2009 NYILR 212 214. See also s 1(xi) of the Muslim Draft Bill discussed below). The uncertainty regarding the exact time when the iddah commences is ignored for purposes of this article. See in general Moosa and Karbanee 2004(2) Law, Democracy and Development 283-284.

11 718. See also Amien 2006 Human Rights Quarterly 729-754.

12 [2009] JOL 23733 (ECP). See discussion below.

13 The most common manner in obtaining a divorce in Islam is for the husband to issue (pronounce) three Talaqs to divorce his wife (Vahed 38). Other possibilities are the Khula and the Faskh, but a discussion hereof falls outside the scope of this article (Gabru 20042 PER 4).

14 Par 13. The court noted that a divorce in Muslim law comes into effect after notification by the husband to the wife of the divorce (talaq) three times (par 2). The disagreement among Muslim scholars regarding the form and place of the talaqs is ignored for purposes of this article. See in general Qasmi The Complete System of Divorce (2002); and Ali Islamic Law of Marriage and Divorce (1949).

15 The wife, in the main civil divorce action, is claiming recognition of her Muslim marriage in terms of South African law; in the alternative, that the Marriage Act 25 of 1961 is unconstitutional in so far as it does not recognise Muslim marriages. In the further alternative, she seeks a declaratory order regarding the Divorce Act 70 of 1979 to include marriages entered into in terms of Islamic law (par 3). 
polygamous wives, has been confirmed in the case of Khan $v$ Khan, ${ }^{16}$ where it was found that as there is a legal duty on a husband to maintain his Muslim wife/wives during the marriage, the Maintenance Act 99 of 1998 is applicable. Similarly, the duty of the husband to support his wife to whom he was still married in accordance with Muslim rites has been recognised for purposes of Rule 43 applications pending a civil divorce action even though the validity of the marriage was challenged. ${ }^{17}$ These aspects are disregarded for purposes of this article - as is the principles relating to the support of a surviving Muslim wife after the death of her husband. ${ }^{18}$

This aim of this article is first, to set out and compare the post-divorce maintenance rules vis-à-vis a wife and children in both the South African law and Islamic law in light of recent case law; secondly, to note the South African legislative initiatives in light of the apparent conflict between the constitutional principles and Islamic law. Thirdly, the legal positions in Algeria and India are noted and compared to the South African system. The article concludes with a call for legislation to be enacted to regulate Muslim marriages and divorces. It is argued that the enactment of such legislation, whether it is in the format of the Muslim Marriage Bill as set out in the 2003 South African Law Reform Commission Report, ${ }^{19}$ or in another format, must take place within the confines of the rulings and teachings of Islamic law.

\section{POST-DIVORCE SPOUSAL MAINTENANCE}

\section{South African family law}

The legal principles of spousal support are trite in the South African law. ${ }^{20}$ There is a reciprocal duty of support between spouses married in terms of civil law, regardless of the chosen matrimonial property system. Depending on the circumstances, the duty may thus also fall on the wife. ${ }^{21}$ The duty to support is terminated upon divorce, although it may in certain circumstances

20052 SA 272 (T) 283D.

17 Cassim v Cassim (Part A) (TPD) (unreported case number 39543/2006 dated 2006-12-15; and Jamalodeen $v$ Moola (NPD) unreported case number 1835/06 as read with Zaphiriou $v$ Zaphiriou 19671 SA 342 (W).

18 See in this regard the case of Amod (born Peer) v Multilateral Motor Vehicle Accidents Fund (Commissioner for Gender Equality Intervening) 19994 SA 1319 (SCA), where a delictual claim for loss of support by a de facto monogamous Muslim spouse against the Road Accident Fund was confirmed. See also Daniels v Campbell 20047 BCLR 735 (CC) for a successful maintenance claim by a de facto monogamous Muslim surviving spouse in terms of the Intestate Succession Act 81 of 1987 and the Maintenance of Surviving Spouses Act 27 of 1990; and Hassam v Jacobs NO (Muslim Youth Movement of South Africa and Women's Legal Trust as Amici Curiae) [2009] ZACC 19 for the (limited) equivalent successful claims by polygamous surviving spouses.

19 SALRC Islamic Marriages and Related Matters Report (Project 59).

20 The equality between spouses inter se and with regard their children is a combination of common law rights as developed through both legislation and judicial precedent.

21 S 7(2) refers to "parties" and not "husband" and "wife" and as a result either spouse can be ordered to pay maintenance, even the wife (Cronje and Heaton South African Family Law 2ed (2004) 147). 
continue after the dissolution of the marriage..$^{22}$ The duty of support must be seen in light of the broader division of the patrimony of the spouses in terms of their chosen matrimonial property system and, if relevant, their antenuptial contract. $^{23}$

The Divorce $\mathrm{Act}^{24}$ makes provision for two possibilities: firstly, parties may conclude a written agreement regarding maintenance in terms of which one party agrees to pay maintenance to the other and this agreement may be made an order of court. ${ }^{25}$ Secondly, in the absence of such an agreement, the court may make an order for maintenance it deems fit in favour of one of the spouses until the death or remarriage of the party in whose favour the order operates. ${ }^{26}$ The Act prescribes the factors which the court may take into account: the existing and prospective means of each party; their respective earning capacities; the financial needs and obligations of the parties; the ages of each of the spouses; the duration of the marriage; their standard of living prior to the divorce; the conduct of the spouses where this is relevant to the breakdown of the marriage $;{ }^{27}$ any redistribution order in terms of s 7(3); as well as any other factor which the court deems necessary to take into account. ${ }^{28}$

In recent years the courts have veered away from granting permanent maintenance until death or remarriage in favour of one spouse against the other depending on the circumstances. ${ }^{29}$ The court seems to favour rehabilitative maintenance for a specific period to enable the party needing maintenance to be trained or retrained towards the establishment in a career. $^{30}$ Alternatively, a notional (token) earning capacity may be attributed to a spouse (often an older spouse) in instances where it is foreseeable that the spouse would require maintenance in future even though he/she may not need it at the date of the divorce. ${ }^{31}$ The token amount may then be increased when maintenance is required. Whether a spouse can be forced to take up employment after the divorce would depend on the circumstances. ${ }^{32}$

22 Van Heerden, Cockrell and Keightley with Heaton, Clark, Sinclair and Mosikatsana Boberg's Law of Persons and the Family 2ed (1999) 235.

23 See in general Cronje and Heaton Chapter 12.

2470 of 1979.

25 Divorce Act s 7(1). Rowe v Rowe 19974 SA 160 (C). Generally with maintenance claims, two aspects must be proved: the need for maintenance by the applicant spouse and the financial ability to support, of the other spouse (Van Zyl Handbook of the South African Law of Maintenance 2ed (2005)).

$26 \mathrm{~S} 7(2)$ of the Divorce Act 70 of 1979

27 Swart $v$ Swart 19084 SA $368(0)$.

28 S 7(2). See in general Robinson, Human, Boshoff, Smith and Carnelley Introduction to the South African Family Law (2009) 203.

29 $\quad$ V v V 19984 SA 616 (C); Kroon v Kroon 19864 SA 616 (E); Joubert $v$ Joubert 20041 All SA 426 (C); and Cronje and Heaton 149.

30 Kroon $v$ Kroon supra.

31 Qosa v Qosa 19894 SA 838 (Ck); and Cronje and Heaton 151.

32 Pommerel $v$ Pommerel 19901 SA 998 (E). Where the husband can afford to pay maintenance and the wife did not work outside the home prior to the divorce, by agreement, the court has held that this situation should continue where it is in the best interests of the children for the mother to remain at home (Grasso v Grasso 19871 SA 48 (C)). 
Section 7(2) of the Divorce Act combines the maintenance order with the decree of divorce, and a maintenance order may not be granted in favour of a former spouse after the marriage has been dissolved. ${ }^{33}$ The post-divorce maintenance order cannot always be seen in isolation. The court may, in light of the clean-break principle, award the wife a lump sum maintenance amount if it deems it fair and equitable. ${ }^{34}$ It is reiterated that the amount of maintenance will depend on the circumstances of each couple and the factors mentioned above. ${ }^{35}$

A maintenance award would generally include support with regard to food, clothing and accommodation although the exact amount is determined by the court, specifically considering the standard of living of the spouses prior to the marriage ${ }^{36}$ The enforcement of maintenance obligations are generally through the maintenance courts ${ }^{37}$ in terms of the Maintenance Act. ${ }^{38}$

\section{Islamic law}

\section{The marriage contract and dowry}

A marriage in Islam is a contract (aqd-un-nikah). The marriage contract is concluded through two essentialia or pillars (arkan) of offer and acceptance by the prospective bride and groom or their proxies. ${ }^{39}$ It is the right of the woman to lay down certain conditions before signing the marriage certificate in order to protect her welfare during the marriage or thereafter. This can be done in a taqliq or a pre-nuptial agreement. ${ }^{40}$ Furthermore, the parties may include any conditions in the marriage contract. ${ }^{41}$ One of the conditions or consequences of a marriage is that the marriage contract will have immediate effect and that it may not be suspended or deferred to the future. ${ }^{42}$

The payment of a dowry $(m a h r)^{43}$ is an indispensable component of an Islamic marriage contract. ${ }^{44}$ It incorporates either a sum of money or

S 8(1). See also Schutte $v$ Schutte 19861 SA 872 (A).

34 S 7(2) as read with Zwiegelaar v Zwiegelaar 20011 SA 1208 (SCA). Cf Cronje and Heaton 151-152 on lump sum payments and 140-141 on the clean break principle. See also Beaumont v Beaumont 19871 SA 967 (A) 994; and Moosa and Karbanee 2004(2) Law, Democracy and Development 280.

35 Van Zyl 3.

36 Ibid.

37 Van Zyl Chapter 8.

3899 of 1998. There are other enforcement possibilities not relevant for purposes of this article. See inter alia Bannatyne $v$ Bannatyne (Commission for Gender Equality, as Amicus Curiae) 20032 SA 363 (CC).

39 Goolam "Islamic Law" in Bekker, Rautenbach and Goolam (eds) Introduction to Legal Pluralism in South Africa (2006) 253.

40 Goolam 253.

$41 \mathrm{Eg}$, that the woman shall retain the right to dissolve the marriage and that the husband may not marry a second wife during the subsistence of the first marriage (Goolam 253).

42 Nasir (1994) 5.

43 The right to dowry is an inalienable right of the wife in that it is taken for granted even if it is not expressly stated in the marriage contract. The dowry should not be equated with bride price as Muslim jurist are unanimous that the dowry has been ordained in order to 
property which becomes payable by the husband to the wife after the prospective spouses agreed to conclude the marriage ceremony. ${ }^{45}$ The reason for the payment of a dowry is to safeguard the woman's economic or financial position after the marriage takes place and she is not obligated to inform, nor consult, her husband as to how the dowry will be used. ${ }^{46}$ The dowry becomes the sole property of the bride. However, the payment of the dowry can be effected in one of three ways, namely: one, transfer of the dowry to the wife immediately on the conclusion of the marriage; or two, the payment thereof may be deferred to a later date; or three, the payment of a portion of the dowry at the conclusion of the marriage and the balance to be paid if and when the marriage is dissolved by divorce or death of the husband. ${ }^{47}$

Where the payment of dowry is deferred, the wife has a claim against the husband in the event of the terminating of the marriage by divorce. In addition, the wife would not lose her right to payment of a dowry through prescription alone ${ }^{48}$ Moosa and Karbanee argues that this is problematic in South Africa as there is a gap between the theoretical rights of a wife and what happens in practice - especially in light of the economic superiority of the husband that remains a reality in this country. ${ }^{49}$ Rajendra Babu $\mathrm{J}$ in the Supreme Court of India described the (same) problem as follows: ${ }^{50}$

"Our society is male dominated both economically and socially and women are assigned, invariably, a dependant role, irrespective of the class of society to which she belongs. A woman on her marriage very often, though highly educated, gives up her all other avocations and entirely devotes herself to the welfare of the family, in particular she shares with her husband, her emotions, sentiments, mind and body, and her investment in the marriage is her entire life a sacramental sacrifice of her individual self and is far too enormous to be measured in terms of money. When a relationship of this nature breaks up, in what manner we could compensate her so far as emotional fracture or loss of investment is concerned, there can be no answer. It is a small solace to say that such a woman should be compensated in terms of money towards her livelihood and such a relief which partakes basic human rights to secure gender and social justice is universally recognised by persons belonging to all religions and it is difficult to perceive that Muslim law intends to provide a different kind of responsibility by passing on the same to those unconnected with the matrimonial life such as the heirs who were likely to inherit the property from her or the wakf boards. Such an approach appears to us to be a kind of distortion of the social facts. Solutions to such societal problems of universal magnitude pertaining to horizons of basic human rights, culture, dignity and decency of life and dictates of necessity in the pursuit of social justice should be invariably left to be decided on considerations other than

emphasize the prestige of the marriage contract and to stress its importance and that dowry has not been ordained as a price or a wage (Goolam 256).

44 Miller 2009 NYILR 213.

45 Nasir (1994) 43. The sum or value of the dowry is neither fixed nor prescribed by Islamic law, but may be agreed on by the parties to the proposed marriage or it may be determined by operation of law, having regard to the social status of the parties (Goolam 255).

46 Esposito Women in Muslim Family Law (1982) 24.

47 Goolam 63.

48 Nasir The Islamic Law of Personal Status (1990) 87.

49 Moosa and Karbanee 2004(2) Law, Democracy and Development 270.

50 Danial Latifi \& Anr v Union of India [2001] INSC 515 (28 September 2001). 
religion or religious faith or beliefs or national, sectarian, racial or communal constraints."

\section{Maintenance}

"The source of all laws on Islam is Allah and Allah alone ..."

The post-divorce maintenance of a wife must be seen in light of the prenuptial agreement, the dowry and the marriage contract, as all three would influence any financial settlement a wife would receive at the time of a divorce. The provisions directly relating to spousal maintenance in Islam are generally accepted. ${ }^{52}$ In terms of Islamic law it is the duty of the husband to support his wife during the marriage (nafaqa). This duty is not reciprocal. The wife is under no obligation to contribute financially towards the running of the household and where she does, she may claim such amounts back from her husband. ${ }^{53}$ Maintenance is regarded as a basic right to which a wife is entitled to as a consequence of marriage and includes food, clothing and accommodation. ${ }^{54}$ Maintenance is a right granted by Allah (God) by holy injunction as it is stated in the Qur'an:

"Let the man of means spend according to his means, and the man whose resources are restricted, let him spend according to what Allah has given him

Let the women live in the same style as you live according to your means; and do not harm them so as to restrict them, and if they are pregnant, then spend your sustenance on them until they deliver their burden. And if they suckle your offspring, give them recompense.

Where the marriage is terminated by divorce, the husband is still obliged to maintain the wife and provide her with accommodation for the period of three months after the divorce - the iddah or waiting period. ${ }^{57}$ Where the wife is pregnant at the time of divorce the husband has to maintain her for the entire duration of the pregnancy as well as during the time that she is breast-feeding the child. ${ }^{58}$ It should be noted, however, that the wife may in certain instances not be entitled to maintenance during the iddah period. ${ }^{59}$

51 Qur'an 6:57; Nyazer Theories of Islamic Law (1996) 37.

52 Qasmi 218; Nasir (1994) 112-113. Gabru notes that a woman is entitled to "reasonable maintenance" at divorce with reference to the Qur'an 2:241 and 2:236-7. See also the view of Moosa and Karbanee mentioned below.

53 Goolam 256.

54 The wife must be properly supported and maintained. A wife is empowered to take from her husband's wealth without his permission so as to sustain herself and her children if he does not provide for her and her children - provided she does this with justice and honesty (Sallie Maintenance and Child-Care According to Islamic Law (2001) 77).

55 Al Talaq 65:7.

56 Al Talaq 65:6.

57 Qur'an 65:6; Qasmi 217.

58 Vahed 32 with reference to Qur'an 65:6. The breast-feeding may last for up to two years (Sakr Family Values in Islam (undated) 48).

59 Nasir notes that where the failure of the marriage was as a result of "some cause of a criminal nature originating from the woman, such as her apostasy or her misbehaviour" she may not have a claim (Nasir (1994) 113). This issue is disregarded for purposes of this article. 
After the three-month iddah period has lapsed, the husband ceases to be responsible for the maintenance of his former wife as they are regarded as strangers. ${ }^{60}$

Moosa and Karbanee disagree with the above interpretation and argue that there is enough scope within the primary sources of Islam to make provision for the continued maintenance of a divorced woman. ${ }^{61}$ However, their own research amongst the Ulama in the Cape shows little support for their view except for the possibility of a consolatory gift to the wife - a gift that is not compulsory and cannot be enforced. ${ }^{62}$

In Islam, the responsibility of the maintenance of the divorced woman reverts to her relatives: her son or father or other relations. ${ }^{63}$ As far as the former wife is concerned, as soon as the iddah period has expired, she no longer has a claim for maintenance against her former husband, although she can claim for child-minding services.

It is reiterated that at the time of the divorce, the wife is also entitled to any unpaid maintenance dues, accumulated during the marriage, and this debt does not prescribe. ${ }^{65}$

The father, besides maintaining his children, is also responsible for the cost of child-care. Where the children are in the custody of the mother, their father is under an obligation to remunerate her for the child-care services which she renders by taking care of their children. ${ }^{66}$ The father/former husband must provide her with housing for her and her children. ${ }^{67}$ Furthermore, he has to provide the food and all other necessaries to ensure that his children are not left destitute and impoverished. ${ }^{68}$

60 268. Qasmi 223; Moosa and Karbanee 2004(2) Law, Democracy and Development 269 with reference to Qur'an 2:223 and 65:1 and 6.

61 They note that while the Hanafi School provides for the maintenance of a wife in all instances, the other three schools of Islam do not (Moosa and Karbanee 2004(2) Law, Democracy and Development 272).

62 Moosa and Karbanee 2004(2) Law, Democracy and Development 283-284.

63 The obligation to maintain an ex-wife shifts to her former family according to the Shari'ah principle that the burden to maintain is borne by whoever stands to inherit from the woman (Vahed 32). The obligation falls on her mature son (Qasmi 228) and if that option is not available, her father. If her father is unable to maintain her, this responsibility falls on her brothers (Qasmi 228). Where there are no brothers, the responsibility falls on the public treasury (known as the Baytul Mal) (Sallie 105). This is problematic as the Baytul Mal has to support the indigent, the homeless and the unemployed and in South Africa the public treasury does not have sufficient funds to support those in need of support adequately. This may result in the wife becoming destitute. Qasmi argues that she can compel her relations to maintain her through Shari'ah institutions (Qasmi 229). As mentioned earlier, Moosa and Karbanee regards this possibility as cold comfort.

64 See discussion below.

65 Expert witnesses' testimony in the case of Ryland $v$ Edros supra $711 \mathrm{f}-\mathrm{g}$. The evidence referred specifically to the Shafi'i school of Islam.

66 Sallie 43.

67 This accommodation must be fully furnished and made comfortable to satisfy their needs (Sallie 43)

68 Sallie 44. 


\section{Comparison}

From the above it is clear that the position in Islamic law with regard to the post-divorce maintenance differs from that in South African law in the following respects: firstly, the duty of maintenance in South African law is reciprocal during the marriage and the duty rests on both the husband and the wife depending on their circumstances, whilst in Islam the duty falls only on the husband. Secondly, in South African law the duty to maintain terminates at the date of the divorce unless there is an agreement between the parties to the contrary or a court order to that effect, whilst in Islam maintenance of the wife terminates three months after the divorce. There is no provision for the duty to continue either by agreement or by a court order. Direct comparison, however, remains problematic as the maintenance issue is only one aspect of the broader division of property at the time of the divorce. It is against this back-drop that the 2009 Port Elizabeth judgment must be read.

\section{Mahomed v Mahomed ${ }^{69}$}

The parties entered into a marriage according to Muslim rites in 1998 and one daughter (born 1999) was born as a result of the marriage. The wife brought a Rule 43 application for maintenance of herself and her child pendente lite. Her husband argued inter alia that they are already divorced in terms of Islamic law. A civil divorce action was pending between the parties wherein the wife claimed a (secular) decree of divorce as well as postdivorce maintenance for herself and her minor daughter. Leaving aside the arguments about the status of the Muslim marriage and divorce in terms of South African law that will only fully be canvassed at trial, Revelas $\mathrm{J}$ confirmed earlier cases that, notwithstanding the fact that the parties were married in terms of Muslim rites, a party was not precluded from obtaining relief in terms of Rule 43. The respondent was inter alia ordered to pay maintenance to the applicant and their minor daughter to the amount of R2 500 and R3 000 respectively, presumably until the date of the (civil) divorce court decision.

This decision by the Port Elizabeth High Court granting maintenance order in favour of a Muslim wife post-divorce appears to be in conflict with the majority of rulings and teachings of Islamic law that once the iddah period has expired, the wife is not entitled to claim for maintenance from her former husband. ${ }^{70}$ To be better aligned with the Shari'ah, she should rather have claimed for child-minding services which she was rendering by taking care of their minor daughter. ${ }^{71}$

\footnotetext{
See fn 12 above.

Qasmi 217. There are exceptions such as in India.

See discussion below.
} 


\section{POST-DIVORCE MAINTENANCE OF CHILDREN}

\section{South African law}

Both parents have a reciprocal duty to support their children during and after the marriage according to their respective means. ${ }^{72}$ In terms of section $18(2)(d)$ of the Children's Act $^{73}$ parental responsibilities and rights are defined to include the duty to contribute to the maintenance of the child. ${ }^{74}$

In general, parents are obliged to maintain their children if the following requirements are met: ${ }^{75}$ one, the parents must have the necessary means to provide maintenance $;^{76}$ and two, the child must require the maintenance and not have the necessary means to provide maintenance for him- or herself. ${ }^{77}$

The extent of the duty of support which parents owe their children is not limited to the basic necessities of life. ${ }^{78}$ The duty entails providing food, clothing, accommodation, medical and dental care and education. ${ }^{79}$ The extent of the duty of support is determined by the social status and financial position of the family and the duty terminates when the child becomes selfsupporting. ${ }^{80}$ The duty of support of parents is generally enforced in the maintenance courts through the Maintenance Act.

\section{Islamic law}

In Islam it is firstly the father who bears the sole, but reciprocal, duty of support towards his children: his sons until the age of majority and his daughters until they are married. ${ }^{82}$ This duty arises by operation of law and as a consequence of the marriage.$^{83}$ It is only where the father is poor that the responsibility of child maintenance falls also on the mother in so far as she is capable of bearing the duty. ${ }^{84}$

\footnotetext{
S 15(3)(a) of the Maintenance Act 99 of 1998.

74 Under common law the parental duty to support a child was not seen as a component of parental power (Cronje and Heaton 291). It is noteworthy that the definition of "care" (custody) also includes the duty to, within available means, provide the child with a suitable place to live, living conditions that are conducive to the child's health, well-being and development and the necessary financial support.

75 Cronjé and Heaton 210; Lamb v Sack 19742 SA 670 (T); and Osman v Osman 19921 SA 751 (W).

76 Ncubu v National Employers General Insurance Co Ltd 19882 SA 190 (N).

77 Gliksman v Talekinsky 19554 SA 468 (W).

78 Mentz v Simpson 19904 SA 455 (A).

79 Oosthuizen v Stanley 1938 AD 322 328; and Van Vuuren v Sam 19722 SA 633 (A) 638641. In appropriate circumstances a child is entitled to a university or any other post-school education (Scott $v$ Scott 1946 WLD 399). 80 Oosthuizen v Stanley supra 322; Hawthorne v Hawthorne 19503 SA 299 (C); Herfst v
Herfst 19644 SA 127 (W); and Cronjé and Heaton 211.

8199 of 1998.

82 Vahed 46.
}

83 Ibid.

84 Ibid. 
The ambit of this duty includes food, clothing, accommodation, education, nursing, medical and dental care. ${ }^{85}$ The father's financial status and his standard of living will determine the level of support. ${ }^{86}$ The following verse in the Qur'an can be cited to substantiate what is stated above:

"The father shall bear the costs of their food and clothing on equitable terms. No soul shall have a burden laid on it greater than it can bear. No mother shall

be treated unfairly on account of her child and neither shall the father be

treated unfairly on account of his child.

The above emphasises the father's responsibility to support his offspring. This position remains unchanged where the parents are divorced. ${ }^{88}$ Where the father fails to honour his financial obligations towards his children, the ex-wife could approach a learned scholar in the Muslim community to remind the errant father of his duty towards his children. ${ }^{89}$ Failing this, application could be made to the maintenance court for an order compelling the father to pay maintenance towards his children. ${ }^{90}$ This interpretation seems to fall within the confines of the rulings and teachings of Islamic law. ${ }^{91}$

\section{Comparison}

The position in Islam is very similar to the South African legal position in that both parents and children have a reciprocal duty to support one another. In Islam, however, the duty falls on the father first and it is only where he is poor that the burden shifts onto the mother if she is capable to maintain her children. The main difference is with the termination date of the maintenance duty.

\section{Mahomed v Mahomed}

If one assesses the case of Mahomed $v$ Mahomed in light of the above, and specifically the order that the father should maintain his daughter (10 years old), there seems to be no conflict with Islamic principles. Had the child, however, been a son, the date of the termination of the maintenance might be an issue as in Islamic law termination is on date of majority and in South African law, on the date when he can support himself. These dates would not necessarily overlap. It is interesting to note that the SALRC Bill makes provision for support of children until they are self-supporting. ${ }^{92}$

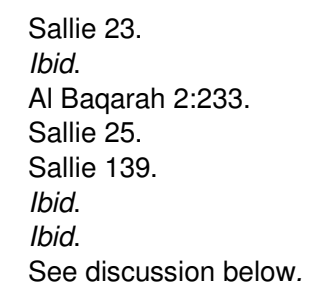




\section{SOUTH AFRICAN LEGISLATIVE INITIATIVES}

\section{SALRC Report ${ }^{93}$}

The recognition of Muslim marriages in terms of civil law has not escaped the scrutiny of the South African Law Reform Commission ${ }^{94}$ The SALRC in its Report on Islamic Marriages and Related Matters ${ }^{95}$ included a Bill (Muslim Marriages Act) ${ }^{96}$ In terms of clause 2, the proposed Act, once promulgated, would only be applicable to spouses where they so choose. ${ }^{97}$

Regarding the termination of Muslim marriages a court granting or confirming a decree for the dissolution of a Muslim marriage would have the powers contemplated inter alia in section 7(1) but not section 7(2) of the Divorce Act. ${ }^{98}$ The court would be able to make an agreement between the parties regarding maintenance an order of court. Added hereto, the court would have to take into account all relevant factors when making an order for the payment of maintenance, including past maintenance. ${ }^{99}$

The Bill proposes that the provisions of the Maintenance Act 99 of 1998 should apply in respect of the duty of any person to maintain any other person. ${ }^{100}$ The proposed clause dealing with maintenance reads as follows:

"[N]otwithstanding $\mathrm{s} 15$ of the Maintenance Act or the common law, the maintenance court must, in issuing a maintenance order, or otherwise in determining the amount to be paid as maintenance, take into consideration that:

(a) the husband is obliged to maintain his wife during the subsistence of a Muslim marriage according to his means and her reasonable needs;

(b) the father is obliged to maintain his children until they become selfsupporting;

(c) in the case of a dissolution by divorce of a Muslim marriage

(i) the husband is obliged to maintain the wife for the mandatory waiting period of 'Iddah;

(ii) where the wife has custody in terms of $s 11$, the husband is obliged to remunerate the wife, including providing a separate residence if the wife does not own a residence, for the period of such custody only;

93 The South African Law Commission has changed its name to the South African Law Reform Commission (SALRC).

94 The issue has been investigated first in 1990 and again in 1996. Amien notes that the lobbying for change has commenced 70 years ago (Amien 2006 Human Rights Quarterly 739). In 2001 the SALRC published the Discussion Paper (SALRC Project 59 Discussion Paper 101 on Islamic marriages and related matters). After consideration of all the submissions and further responses the 2003 Report was published. See in general Goolam 162-163.

95 Project 59 dated July 2003. The Report was issued after wide consultations were held with interest groups (Report Annexures $C$ and $D$ ).

96 Report 110-133 (Annexure A).

97 It is proposed for both existing and new Muslim marriages. Parties can elect not to have the legislative provisions applicable to their marriage (clause 2).

98 Clause 9(7)(a).

99 Clause 9(7)(f)

100 Clause 12(1). 
(iii) the wife shall be separately entitled to be remunerated (ujrah al-hadānah) in relation to a breast-feeding period of two years calculated from date of birth of an infant;

(iv) the husband's duty to support a child born of such marriage includes the provision of food, clothing, separate accommodation, medical care and education."

Furthermore, the amount of maintenance determined by the court should be fair and just in light of all the circumstances. ${ }^{102}$ Interestingly, although a few persons or groups that made submissions to the SALRC argued in favour of post-iddah maintenance, ${ }^{103}$ it was not included in the Bill.

The major flaw of the SALRC Report, however, remains the fact that it does not deal directly with the constitutional and international law issues. ${ }^{104}$

The Report as a whole, including the Bill, remains controversial and little progress has been made since 2003 although it has been submitted that the draft Bill could alleviate the hardships that result from the non-recognition of Muslim marriages. ${ }^{105}$ The major stumbling block seems to be the lack of consensus within the Muslim community about the way forward. ${ }^{10}$

Several Islamic groups recently attempted to force the hand of the legislature to enact Muslim marriage and divorce legislation by directly approaching the Constitutional Court for relief in Women's Legal Centre Trust $v$ President of the Republic of South Africa (with the United Ulama Council of South Africa as Amici Curiae). ${ }^{107}$ The WLC argued that the Constitution obliges the President and Parliament to prepare, initiate, and enact the legislation envisaged, "but that they have taken no meaningful steps to pass such legislation since July 2003 ". ${ }^{108}$ They noted that their failure infringed inter alia on the right to equality, ${ }^{109}$ the right to dignity, ${ }^{110}$ the

101 Clause 12(2). Unpaid arrear maintenance which is due and payable to a wife shall not be capable of being extinguished by prescription, notwithstanding the provisions of the Prescription Act 68 of 1969 or any other law (clause 12(5)).

102 Clause 12(3).

103 SALRC Collation on the Discussion Paper 101 (2002) 23, 37 and 39 with reference to the submissions of Bulbulia; Toefy Sali, Islamic Careline and the Women's Legal Center.

104 Amien 2006 Human Rights Quarterly 745.

105 Goolam 165.

106 Although it is easy to say that the guiding principle of the legislation should be the Qur'an and the Shar'iah, differences in interpretation exist that complicate matters (Amien 2006 Human Rights Quarterly 746 as read with SALRC (2000) Annexure A 35).

107 [2009] ZACC 20.

108 Par 9.

109 Constitution (s 9): (1) Everyone is equal before the law and has the right to equal protection and benefit of the law. (2) Equality includes the full and equal enjoyment of all rights and freedoms. To promote the achievement of equality, legislative and other measures designed to protect or advance persons or categories of persons, disadvantaged by unfair discrimination may be taken. (3) The state may not discriminate unfairly directly or indirectly against anyone on one or more grounds, including race, gender, sex, pregnancy, marital status, ethnic or social origin, colour, sexual orientation, age, disability, religion, conscience, belief, culture, language and birth. (4) No person may discriminate unfairly directly or indirectly against anyone on one or more grounds in terms of subsection (3). National legislation must be enacted to prevent or prohibit unfair discrimination. (5) Discrimination on one or more of the grounds listed in subsection (3) is unfair unless it is established that the discrimination is fair. 
right to freedom of conscience, religion, thought, belief and opinion, ${ }^{111}$ the right to participate in the cultural life of one's choice ${ }^{112}$ and the right to enjoy and practise religion. ${ }^{113}$ The court, however, found that the legislative programme and duties of the government should not be brought directly to the Constitutional Court, but must first be lodged in the High Court and go through the ordinary judicial processes to ensure the issues are argued in detail. The application which sought an order to oblige the President, the Ministers for Justice and Constitutional Development and for Home Affairs, and the principal office-bearers of Parliament to enact legislation regulating Muslim marriages was refused. ${ }^{114}$

\section{Constitutionality}

The main legal issue with the draft legislation is the constitutionality thereof. The Constitution guarantees on the one hand the right to equality with no discrimination based on inter alia religion; ${ }^{115}$ and on the other hand, the right to cultural and religious freedom. ${ }^{116}$ In comparing these principles with Muslim personal laws there seems to be a conflict and such comparison has the potential to result in a "constitutional tug-of-war." 117 The possible unconstitutionality has been well documented and is not repeated herein. Focusing only on the provisions quoted above, the question is whether these maintenance provisions would survive a constitutional challenge?

Using the Harksen $v$ Lane $N O^{118}$ multi-stage enquiry to determine the constitutionality of these provisions, the first step is to determine whether the provisions differentiates between people or category of people. If the answer is in the negative, there is no violation of the right to equality. If the answer is "yes", the second step is to determine whether the differentiation amounts to unfair discrimination. ${ }^{119}$ This again is a two-stage analysis: one, does the

110 Constitution (s 10).

111 Constitution (s 15): (1) Everyone has the right to freedom of conscience, religion, thought, belief and opinion. (2) Religious observances may be conducted at state or state-aided institutions, provided that (a) those observances follow rules made by the appropriate public authorities; (b) they are conducted on an equitable basis; and (c) attendance at them is free and voluntary. (3)(a) This section does not prevent legislation recognizing (i) marriages concluded under any tradition, or a system of religious, personal or family law; or (ii) systems of personal and family law under any tradition, or adhered to by persons professing a particular religion. (b) Recognition in terms of paragraph (a) must be consistent with this section and the other provisions of the Constitution.

$112 \mathrm{~S} 30$ of the Constitution.

$113 \mathrm{~S} 31$ of the Constitution.

114 Par 26.

115 See fn 107 above. This section must be read with the Promotion of Equality and Prevention of Unfair Discrimination Act 4 of 2000.

116 See fn 109 above. An example of such recognition can be seen in the Recognition of Customary Marriages Act 120 of 1998.

117 Goolam 170; Amien 2006 Human Rights Quarterly 752-753; and Cronje and Heaton 222. It would be unnecessary to repeat these arguments herein

11819981 SA 300 (CC) par 53; and Promotion of Equlity and Prevention of Unfair Discrimination Act 4 of 2000 (s 2(b)(ii)-(iv))-2(c)).

119 Par 5. 
differentiation amount to discrimination; and two, if so, does it amount to unfair discrimination? ${ }^{120}$

Applying the first step, it is noted that the provision differentiates between people or category of peoples inter alia in the following manner: one, in Islamic law the maintenance duty between spouses is not reciprocal as only the husband is obliged to maintain his wife; two, similarly, initially only the husband is liable to maintain his children and not the wife. This is different from the South African law where the duty to maintain may also fall on the wife. Three, post-divorce maintenance of a Muslim ex-wife is limited to the iddah period whilst in the South African law it could end at the date of divorce unless there is an agreement between the spouses or a court order to the contrary. Four, the provision in the Bill that the husband is obliged to remunerate a custodian wife (including providing a separate residence if the wife does not own a residence) for the period of such custody only, is unknown in South African law and not available to divorced women in terms of civil law. Five, the provision in the Bill that the wife is separately entitled to be remunerated in relation to a breast-feeding period of two years calculated from date of birth of an infant is also unknown to the South African law and not available to divorced women in terms of civil law.

The answer to the first stage of the enquiry is thus in the affirmative. The next question is therefore if the differentiation amounts to discrimination and if so, whether it is unfair. The differentiation prima facie amounts to discrimination as it grants more favourable recognition and consequences to different types of spouses. The concept that men alone are responsible for the maintenance of the family is discriminatory in itself. ${ }^{12}$ As the discrimination is on more than one ground, it is regarded as prima facie unfair. ${ }^{122}$ In applying the limitation clause and with regard to the unfairness, Cronje and Heaton argue that because sex equality and human dignity are key founding constitutional principles and values, the court would be reluctant to hold that the violation is reasonable and justifiable in an open and democratic society. ${ }^{123}$ Both Goolam ${ }^{124}$ and Amien ${ }^{125}$ agree that equality would outweigh both culture and religion.

Amien argues, citing Brems, that where possible, both rights should be protected and that a conflict should be avoided. If the Islamic principles cannot be interpreted to give a woman equal rights, a compromise should be made for both rights so that one is not subordinate to the other. Exactly how

\footnotetext{
Goolam 165-166.

1 Goolam 170.

22 Constitution (s 9(5)). The limitation clause, s 39, is disregarded for purposes of this article.

123 Cronje and Heaton 222. A fuller discussion of the limitation clause, s 39, falls outside the scope of this article.

124 Goolam 70. Mashour "Islamic law and gender equality - could there be a common ground?: a study in divorce and polygamy in Sharia law and contemporary legislation in Tunisia and Egypt" in Human Rights Quarterly 2005 27(2) 562 argues that because of the Islamic principles of justice and welfare there is some room for common ground between Islamic law and gender equality.

125 Amien 2006 Human Rights Quarterly 752-753.
} 
this is achieved is not stated. Only if a compromise is not possible should a choice be made between the rights.

Goolam states that it may be argued that women, who choose to live their lives according to their custom and religion, even though they are unequal to their male counterparts, cannot contest the constitutionality of the rules that are a part of such custom and religion. ${ }^{127} \mathrm{He}$, however, disagrees herewith as the contention implies that women are subject to these rules regardless of their social position within that system. Such a conclusion would deter the transformation of all spheres of South African society based on equality and human dignity - specifically as the State is under a constitutional obligation to promote equality and failure to take positive measures could in itself amount to unfair discrimination. ${ }^{128}$ Equality is after all the right of all women. ${ }^{129}$

The courts have not yet had the opportunity to apply the equality jurisprudence to claims brought by Muslim women, ${ }^{130}$ but when it happens the constitutional principles cannot be ignored. ${ }^{131}$ The question, however, remains whether it is possible to draft constitutional legislation that is at the same time both constitutional and not in conflict with Islamic law. This could prove to be problematic, as although section 15(3)(a) by implication recognises the family law system of Islam, it does provide that such recognition must be consistent with the other provisions of the Constitution. This seems to be bound to create conflict. However, Goolam ${ }^{132}$ suggests that the fundamental question which needs to be answered is the following:

"Why should Western ideas and philosophy serve as the yardstick, particularly in South Africa, an African country? A further crucial question is: Why should a legal system such as Islam, based as it is on divine revelation, play second fiddle to a secular, human system?"

In the search for a solution, the following analogy is relevant. In the same way as Islamic laws relating to maintenance could be regarded as discriminatory on the grounds of gender, the same is true about polygamy and the payment of lobola with regard to marriages entered into in terms of the Recognition of Customary Marriages Act. ${ }^{133}$ In deciding whether the recognition of a customary marriage is inconsistent with the Constitution, the SALRC had to weigh the argument, that polygamy prejudices women, against the claim that polygamy performs a valuable social function. ${ }^{134}$ The

126 Amien 2006 Human Rights Quarterly 752 with reference to Brems "Conflicting Human Rights: An Exploration in the Context of the Right to a Fair Trial in the ECHR" 2005 Human Rights Quarterly 294 302-03. Amien also refers to Sullivan who argues for a balancing of the rights in light of all the factors of the case (Amien 2006 Human Rights Quarterly 753 with reference to Sullivan "Gender, Equality and Religious Freedom: Towards a Framework for Conflict Resolution” 1992 NYU Journal for International Law and Politics 795).

Golam 169-170.

128 Goolam 170.

129 Ibid. See also NCGLE v Minister of Home Affairs 20002 SA 1 (CC) par 35.

130 Goolam 169.

131 Constitution s 8(1).

132 Goolam 120.

133120 of 1998 .

134 South African Law Commission Report on Customary Marriages (1998) 87. 
SALRC submitted that while the Constitution upholds non-discrimination, if recognition of customary law is to be something more than an empty gesture towards the African cultural tradition, the Bill of Rights must be construed in a manner that a set of western values does not become dominant - merely due to the fact that customary law is different. ${ }^{135}$ The SALRC further submitted that despite the fact that the present constitutional dispensation is largely based on western values, this did not mean that African values should be completely discarded. Rather, the Constitution should be regarded as an honest attempt to merge both western and African values. ${ }^{136}$ The Recognition of Customary Marriages Act retained the aspects of polygamy and lobola despite the fact that it could be regarded as discriminatory. Should a similar approach not be followed vis-à-vis Muslim marriages and divorces?

Another analogy may be relevant. A surviving spouse is entitled to maintenance from the estate of the deceased spouse if reguired. ${ }^{137}$ The majority of the Constitutional Court in Volks NO v Robinson ${ }^{138}$ found that a heterosexual cohabitee does not have this right to claim maintenance after the death of her partner. The court in essence held that a woman has to suffer the consequences of her choice not to marry her partner in life. The court argued that it would be inappropriate to impose a duty upon the estate of a person where no duty arose by operation of law during the lifetime of the deceased. ${ }^{139}$ Could it not be argued that it would similarly be inappropriate to hold a Muslim husband to consequences that are different at the time of the divorce than what he negotiated for when he got married?

A last comment: the court has the power to develop the common law and customary law, ${ }^{140}$ but not any other legal systems such as the Muslim personal law. The courts would in theory be able to declare a Muslim personal law rule unconstitutional, but it would not be able to develop it or fill the vacuum. ${ }^{141}$ It is submitted that this would leave the religious in a very uncomfortable position to say the least. Khan notes that the notion for a Muslim that a human being can modify or repeal portions of a divine text is fundamentally contrary to the Islamic notion that God is authoritative and the belief that His law should be obeyed and not be abrogated after finding fault with its purpose or its wisdom. ${ }^{142}$

\section{Conclusion}

Whilst it is recognised that religious-based marriages, like marriages entered into in terms of Islamic law, are often considered to be discriminatory on the grounds of gender, it is submitted that such discrimination should be allowed

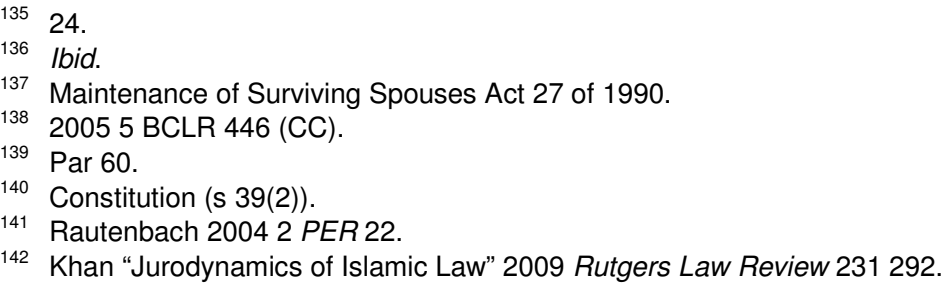


in so far as it is required by the tenets of the religion. Parties who enter into a marriage in terms of Islamic law are not forced to do so as the consent of both parties to the marriage is required. Therefore, if the parties choose to enter into a marriage in terms of Islamic law, they have to accept the consequences which arise from such marriage. Although this again could be regarded as cold comfort for women, the same could be said for heterosexual cohabitees. It is submitted that a different solution should be sought which does not interfere with the tenets of Islam.

\section{FOREIGN LAW}

The interaction between the divine and secular law is not unique to South Africa.

"Within the Muslim world, the legal systems may be broadly divided into three groups: those countries which have retained the practice of the Shar'iah unchanged and uncodified; those countries which have abandoned the Shar'iah and replaced it with secular law; and those countries where the Shar'iah has been changed through modern legislative process.'

It is only the last group that is of interest to the South African legal system for purposes of this article and two jurisdictions, Algeria and India, have been chosen for comparison and will be discussed hereunder. ${ }^{144}$

\section{Algeria}

The Algerian legal system is based on French and Islamic law. ${ }^{145}$ The courts apply Maliki principles in matters relating to marriage as this is the predominant Islamic school of thought in Algeria. ${ }^{146}$ The first Constitution, enacted in 1964, declared Islam the state religion and this was confirmed by the 1976 Constitution. ${ }^{147}$ The Algerian Code of Family Law ${ }^{148}$ codified and regulates the law relating to the family in Algeria. The Code is arranged into four books covering the following aspects: marriage and its dissolution, legal representation, succession and provisions relating to wills, legacies, gifts and assets held in trust. ${ }^{1}$

As far as maintenance during the subsistence of the marriage is concerned, art 39 provides that the husband as the head of the household

143 SALRC (2002) in Annexure 1 discusses the legal position in the following countries: Pakistan, Egypt, the Philippines, and Palestine and Israel.

144 See Moosa and Karbanee 2004(2) Law, Democracy and Development 276 for discussions of the laws in Egypt, Morocco and Tunisia where a more equitable distribution is made after a divorce by the giving of a consolatory gift to the wife by her husband.

145 An-Na'im Islamic Family Law in a Changing World: A Global Resource Book (2002) 165.

146 See fn 1 above.

147 Constitution (article 2) declares that Islam is the religion of the State of Algeria.

148 Law no 84.11 of 9 June 1984 (The Code). The Code was partially reformed on 27 February 2005. The reformation strengthened the position of divorced women with children by giving them the right to stay in their former conjugal homes. Gray Women in Algeria Today and the Debate Over Family Law Middle East Review of International Affairs (MERIA) Vol 13(1) (2009) 4549.

149 Bainham The International Survey of Family Law (1994) 2. 
has the duty to support his wife which includes the selection of a home suitable to receive her. ${ }^{150}$ The husband's obligation to provide maintenance arises from the time the marriage is consummated. Maintenance by the husband is the lawful right of the wife, irrespective of her means or her religion. ${ }^{151}$ Furthermore, the duty to maintain entails as it provides that maintenance involves the provision of food, clothes, medical care, housing or rent and all that is considered necessary in custom and practice. ${ }^{152}$

With regard to maintenance after divorce of the marriage, the husband's liability to maintain his ex-wife continues until the expiry of the period of iddah or until the delivery and breast-feeding of her child if the marriage is dissolved during her pregnancy. ${ }^{153}$ During the iddah period the wife is not required to vacate the matrimonial home, however, thereafter her right to occupy the matrimonial home becomes less certain. ${ }^{154}$ The divorced wife has the right to look after her children and may not be forced to return to her father or other guardian, but the husband still must have a home available to him. ${ }^{155}$ In conclusion, the position in Algeria seems to be in line with the traditional interpretation as the law relating to spousal rights and obligations follows classic Islamic law. ${ }^{156}$

\section{India}

As in South Africa, the Indian Constitution includes the right to equality ${ }^{157}$ and the right to freedom of religion. ${ }^{158}$ Section 44 of the Constitution provides that the State must endeavour to ensure a uniform civil code for all the citizens throughout the territory.

Various statutes deal with the application of Muslim law inter alia the Shar'iah Act, ${ }^{159}$ setting out the rules inter alia regarding marriage and divorce where both parties are Muslim. ${ }^{160}$ Furthermore, in line with $s 44$ of the Constitution, the 1973 Criminal Procedure Code confers a "right of maintenance on divorced wives so long as they remained unmarried". ${ }^{161}$

150 Verse 6 of Sura Talaq of the Qur'an.

151 Nasir (1994) 64.

152 Article 37 as read with 78. These duties conform to the principles set out in Sura Al Baqara verse 231 and Sura Talaq verse 7 of the Qur'an.

153 Article 61.

154 Bainham 23

155 Article 52 par 2 and 3 . Although art 52 clearly states that the husband may allow his wife and children to live in the family home, this is only possible where he possesses more than one house, a rarity in Algeria, where there are housing shortages. In addition, art 52 allows the man the discretion as to whether he wishes to be generous or not to his former wife (Salhi Algerian Women, Citizenship and the 'Family Code' Gender and Development Vol 11(3) (2003) 27 31)

156 An-Na'im 168.

157 Constitution of India, 1950 (s 14).

158 S 25

1591937.

160 See in general SALRC (2000) Annexure A 15.

161 Act II of 1974 (s 125). This Code controls the proceedings and overrules the personal law of the parties (Danial Latifi \& Anr v Union of India supra 515). See discussion by Moosa and Karbanee 2004(2) Law, Democracy and Development 274. 
Based on this section, the Supreme Court of India has ruled that a husband must pay maintenance to his Muslim ex-wife after their divorce - even after the iddah period has expired - until her remarriage or death. ${ }^{162}$ The basis for these findings is the statutory provision as read with Ayat No 241: "And for divorced women, is mataa'am bil ma'roof, which is the right upon the believers" ${ }^{163}$ The court held that the issue of spousal support for Muslim women should be decided in light of her financial need and that religious personal law cannot override secular law in matters of social welfare and public policy. ${ }^{164}$

These decisions have been controversial. The first judgment, Shah Banu, ${ }^{165}$ almost caused a constitutional crisis in India. ${ }^{166}$ The facts were simple: Shah Banu was a Muslim wife over the age of 70 that was divorced by her husband. The court ${ }^{167}$ granted her maintenance until her remarriage, based on the (secular) law, and overruling the husband's objection that in terms of Islamic law she is not entitled to maintenance. ${ }^{168}$ Islamic leaders rejected the decision as an unlawful interference with Muslim personal law and argued that the secular courts took it on themselves to interpret the Qur'an and thus disturbed the understanding of India's society which was based on privacy and the autonomy of the chosen personal law. ${ }^{169}$ Shah Banu herself eventually wrote a public letter declaring that as a true believer she now understood that her actions were wrong and that as a good Muslim she was rejecting the decision of the Supreme Court. She thanked the religious leaders for saving her. ${ }^{170}$

One of the fiercest critics of the decision, Qasmi, argues that the interpretation of the court of the rules was wrong and opines that the only post-divorce maintenance that is due is that during the iddah period. ${ }^{171}{ }_{172}^{\mathrm{He}}$ states that the interpretation by the courts was historically unknown. ${ }^{172}$ Furthermore, he argues that where the husband is grudgingly ordered to maintain his ex-wife after the iddah, it would be haraam ${ }^{173}$ for the wife to consume such maintenance, as it would fall into the category of usurped wealth that should be returned to the ex-husband. ${ }^{174}$ Moreover, according to him, India or any secular state that applies its own "man-made logic" to resolve Islamic maintenance matters does a great injustice to Muslim

162 Iqbal Bano $v$ The State of U.P and Anr [2007] INSC 682 (5 June 2007); Mohd Ahmed Khan $v$ Shah Bano Begum \& Ors [1985] INSC 99 (23 April 1985). See also Qasmi 217.

163 Mohd Ahmed Khan v Shah Bano Begum \& Ors supra 109. See also Qasmi 217; Moosa and Karbanee 2004(2) Law, Democracy and Development 271.

164 Narain "Muslim Women, Family Law and Equal Citizenship in India" 2007 Journal of Semitics 498503.

165 Mohd Ahmed Khan v Shah Bano Begum \& Ors supra 99.

166 Narain 2007 Journal of Semitics 503. See also SALRC (2002) 18; Moosa and Karbanee 274.

167 It is noteworthy that all five the judges were Hindu (Moosa and Karbanee 274).

168 Narain 2007 Journal of Semitics 503.

169 Ibid; Moosa and Karbanee 2004(2) Law, Democracy and Development 274.

170 Narain 2007 Journal of Semitics 506.

171 Qasmi 222.

172 Qasmi 218.

173 Translated as "forbidden".

174 Qasmi 224. 
society. ${ }^{175}$ He notes that it actually is to the detriment of women where the court makes an order for maintenance until remarriage, as it may close the divorce door on her. Her husband, fearing a lifetime of maintenance dues, would think twice before divorcing her. ${ }^{176}$ Added hereto, he highlights that a consequence of such maintenance orders could lead to women opting to "sit idle" and be single for the rest of their lives since a second marriage would be almost impossible. ${ }^{177}$ Qasmi suggests that where the court makes such an order as in the Shah Banu matter, the court should add a condition that the ex-wife must work for the ex-husband as a "normal worker (maid, etc)" so that he at least is obtaining some sort of benefit from the maintenance he is paying. ${ }^{178}$ This opinion does not seem to be widely held.

In India a massive campaign was organized against the Shah Banu decision. The protest ultimately resulted in the adoption of the Muslim Women's (Protection of Rights upon Divorce) Act, 1986. This Act excludes Muslim women from the application of secular law of spousal maintenance that applies to all other women in India. ${ }^{179}$ The post-divorce maintenance was returned to the iddah period only. Thereafter, she ought to be supported in terms of the rules of Islam. ${ }^{180}$

Subsequent hereto, in the Lafiti case, the constitutionality of the 1986 Act was challenged and the Supreme Court re-affirmed the Shah Banu judgment. ${ }^{181}$ The court ruled that the Act was not unconstitutional since it could be interpreted broadly to ensure that Muslim women enjoy the same rights as other women in India. ${ }^{182}$ What is noteworthy is that the courts are reluctant to make a finding on the constitutionality of a personal law system. ${ }^{183}$

\section{CONCLUSION}

In comparing the post-divorce maintenance rules for a wife and children in the South African law with the Islamic Personal laws, it seems obvious that there are fundamental differences between the two systems with regard to the rights of the wives. However, the ad hoc granting of civil law rights and consequences, which flow from civil marriages, to women married in terms of Muslim law by the South African judiciary is problematic. It creates uncertainty for both parties entering into a Muslim marriage. The underlying

175 Qasmi 218.

176 Qasmi 225.

177 Qasmi 226. The problem in India relating to the enforcement of these orders in instances where the ex-husband is financially unable to pay the maintenance is disregarded for purposes of this article. See Qasmi 227.

178 Qasmi 227.

179 Narain 2007 Journal of Semitics 504; Moosa and Karbanee 2004(2) Law, Democracy and Development 274.

180 See discussion above.

181 Danial Latifi \& Anr v Union of India supra 515.

182 Narain 2007 Journal of Semitics 508. It is ironic that this judgment did not cause the outrage that Shah Banu caused. This is put down to the current political situation prevailing in India (Moosa and Karbanee 2004(2) Law, Democracy and Development 275).

183 Narain 2007 Journal of Semitics 509. 
question to the debate is whether there should be secular interference with Islamic principles - whether for fear of contamination or dread of a possible clash with the South African constitutional principles.

In light of the hardship caused by the non-recognition of Muslim marriages, especially for women, it seems as if the only way forward would be to provide clarity through legislation. This legislation would be important to resolve the conflict between the constitutional principles and the Islamic Personal law as was done by the Recognition of Customary Marriages Act for customary marriages. The enactment of such legislation, whether it is in the format of the Muslim Marriage Bill as set out in the 2003 South African Law Reform Commission Report, or in another format, must, however, take place within the confines of the rulings and teachings of Islamic law. This can only be done with the participation of the Islamic community. Broadly speaking there is common ground to be found between Islam and the Constitution as both are aimed at justice and equity. The issue cannot be left to the courts to resolve and in this regard the process in India should serve as a lesson in how not to deal with the issue. Unfortunately, notwithstanding the SALRC initiatives, there has been little progress in the adoption of such legislation.

As far as maintenance post-iddah is concerned, notwithstanding the calls by a few groups to the contrary, the rules seem to be favouring the view that there is no such an obligation beyond the iddah period in Islamic law. The solution to women in need after a divorce should be found elsewhere and on various levels, inter alia in education to ensure that the possibilities created by the marriage contract, the inclusion of a consolatory gift, the payment of arrear maintenance and the dowry are ultimately utilised to their full extent to benefit of the ex-wife. 